\title{
Decreased plasma adiponectin concentrations in women with low-grade C-reactive protein elevation
}

\author{
Miyao Matsubara, Katsuhiko Namioka and Shinji Katayose ${ }^{1}$ \\ Division of Endocrinology and Metabolism, Otaru City General Hospital, Otaru 047-8550 and ${ }^{1}$ Otsuka Assay Institute, \\ Sapporo 060-0061, Japan
}

(Correspondence should be addressed to M Matsubara; Email: miyamatsuba@proof.ocn.ne.jp)

\begin{abstract}
Objective: Inflammation has been suggested as a risk factor for the development of atherosclerosis, while some components of metabolic syndrome $X$ have been related to inflammatory markers. We hypothesized that adipocyte secreting protein, adiponectin and leptin, for which have been demonstrated an association with metabolic syndrome $\mathrm{X}$ and coronary artery disease, may be associated with inflammatory markers in nondiabetic humans.

Design and methods: We measured high-sensitivity C-reactive protein (hs-CRP), as an inflammatory marker, and adiponectin and leptin concentrations in 384 nondiabetic Japanese women (mean \pm S.E.M. age $53.6 \pm 0.8$ years, body mass index (BMI) $23.0 \pm 0.2 \mathrm{~kg} / \mathrm{m}^{2}$ ) undergoing measurement of markers of metabolic syndrome X.

Results: The women who had a low-grade hs-CRP elevation $(>2.0 \mathrm{mg} / \mathrm{l})$ were significantly older and had higher BMI, body fat mass (BFM), total cholesterol (TC), triglyceride (TG), atherogenic index $(\mathrm{AI}=(\mathrm{TC}-\mathrm{HDLC}) / \mathrm{HDLC})$, where HDLC is high-density lipoproten-cholesterol), fasting blood glucose and leptin concentrations before and after adjustment for BMI or BFM, while lower HDLC and adiponectin concentrations before and after adjustment compared with women with normal CRP levels $(<0.5 \mathrm{mg} / \mathrm{l})$. BMI, BFM, TG, AI and leptin before and after adjustment were found to be correlated with hs-CRP levels, while HDLC and adiponectin before and after adjustment were inversely correlated (all $P<0.0001$ ). hs-CRP was independently associated with white blood cell count, blood urea nitrogen and AI and inversely with adiponectin/BFM in the stepwise regression analysis model. Conclusions: These data demonstrate a significant decrease in plasma adiponectin in low-grade chronic inflammation, and suggest that there is an important linkage between inflammation/adipose tissue/atherosclerosis.
\end{abstract}

European Journal of Endocrinology 148 657-662

\section{Introduction}

Adiponectin is a product of the adipose most-abundant gene transcript 1 gene, which is specifically and highly expressed in human adipose tissue, and belongs to the soluble defense collagen superfamily (1). Experimental data indicate that adiponectin reduces tumor necrosis factor (TNF- $\alpha$ ) effects in macrophages and endothelial tissue, suppressing the expression of nuclear transcription factor- $\mathrm{kB} \mathrm{mRNA}$, inhibiting the expression of adhesion molecules critical for monocyte attachment and adhesion to the endothelial wall $(2-5)$. Therefore, it has been suggested that adiponectin possesses antiatherogenic and anti-inflammatory properties $(2-5)$. Plasma adiponectin concentrations have been reported to be decreased in obesity $(6,7)$, type 2 diabetes (8), insulin resistance $(9,10)$, dyslipidemia (11) and coronary artery disease (CAD) (3). Recent data suggest that adiponectin may play a role in the development of metabolic syndrome $\mathrm{X}$, and hypoadiponectinemia can be considered a risk factor for CAD (3-6, 8-11). However, clinical evidence regarding a potential anti-inflammatory effect of this protein has not been found. Leptin, the obese gene product, is a signal to the central nervous system of energy stores in the adipose tissue and a regulatory signal for a variety of other physiological processes in addition to body weight maintenance $(12,13)$. Leptin plays a role in fat metabolism and correlates with insulin resistance and other markers of metabolic syndrome $\mathrm{X}$ independently of total adiposity $(12-14)$.

While inflammation plays a major role in determining atherosclerotic plaque vulnerability, low-grade chronic inflammation is associated with an increased risk of atherosclerotic cardiovascular disease $(15,16)$. Endothelial cell activation is an early event in atherogenesis, and previous studies have reported correlations between indirect markers of endothelial cell activation 
and C-reactive protein (CRP) concentration, a sensitive marker of inflammation. A relationship between plasma high-sensitivity CRP (hs-CRP) levels and the development of atherosclerotic disease has been observed in experimental and epidemiological studies (15-18). Recent evidence suggests that CRP correlates with adiposity and insulin resistance independently of body mass index (BMI), and that the inflammatory marker predicts risk of diabetes $(17,18)$. However, the nature of the association of CRP with metabolic syndrome $\mathrm{X}$ is poorly understood.

We hypothesized that circulating CRP levels may be associated with adipocyte secreting protein, adiponectin and leptin concentrations; such an association would potentially provide insights into the role of CRP in atherosclerotic disease and further clarify the association of inflammation/adipose tissue/atherosclerosis linkage in vivo. Therefore, we cross-sectionally examined associations of serum hs-CRP, adiponectin, leptin concentrations and several parameters of metabolic syndrome $\mathrm{X}$ in nondiabetic subjects. Because sex differences have been reported in plasma adiponectin (6), leptin (13), triglyceride (TG), high-density lipoproteincholesterol (HDLC), uric acid (UA) and percent body fat mass (BFM) (11), we chose to study women only.

\section{Subjects and methods}

\section{Participants}

The original design of this cross-sectional study had been described previously $(7,11)$. Briefly, 384 Japanese women residing in Hokkaido, Japan, aged 16-86 years (mean \pm S.E.M 53.6 \pm 0.8 years) were included in this cross-sectional study. Women taking the birth control pill and postmenopausal hormone replacement therapy, and any with diabetes mellitus, renal failure, untreated endocrine diseases or clinically significant infectious diseases were excluded. Systolic $(\geqq 160 \mathrm{~mm}$ $\mathrm{Hg})$ and diastolic hypertension $(\geqq 90 \mathrm{~mm} \mathrm{Hg})$ were observed in 29.6 and $20.7 \%$ respectively, while 54 were receiving calcium channel blockers, angiotensin converting enzyme inhibitors, or both. Approximately 34.7 and $12.0 \%$ of females had high serum total

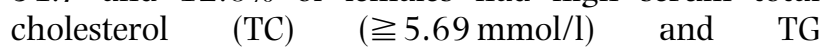
$(\geqq 1.69 \mathrm{mmol} / \mathrm{l}) \quad$ respectively. Overweight $\quad$ (BMI $\geqq$ $25.0 \mathrm{~kg} / \mathrm{m}^{2}$ ) and insulin resistance (homeostasis model assessment (HOMA) $\geqq 3.0$ ) were observed in 24.9 and $11.5 \%$ respectively. Percent BFM was determined by bioelectrical impedance analysis $(7,11)$. All subjects reported that their body weight had been stable $( \pm 2 \mathrm{~kg})$ for at least 3 months before the study, and they provided informed consent.

\section{Biochemical analyses}

Blood samples after overnight fasting were collected for various biochemical analyses using commercially available kits. CRP levels were determined with a clinically validated high-sensitivity assay with use of latex-photometric immunoassay on an automated autoanalyzer (TBA-200FR; Toshiba, Tokyo, Japan). Atherogenic index (AI) was calculated by the formula $\mathrm{AI}=(\mathrm{TC}-\mathrm{HDLC}) / \mathrm{HDLC}$, and HOMA by using fasting blood glucose (FBG) and insulin concentrations $(7,19)$. Assuming that normal-weight normal subjects $<35$ years of age have an insulin resistance of 1 , the value for insulin resistance can be assessed by the formula: FBG $(\mathrm{mmol} / \mathrm{l}) \times$ fasting insulin $(\mu \mathrm{U} / \mathrm{ml}) / 22.5$. The results of the HOMA ratio correlated well with the measurements obtained by means of the euglycemic clamp technique, as was shown in the HOMA method validation study $(7,19)$. Blood samples for measurement of fasting plasma adiponectin concentrations were drawn with 1/10 volume EDTA-aprotinin tubes, and immediately placed on ice. All tubes were centrifuged at $4^{\circ} \mathrm{C}$ for collection of plasma and stored at $-80^{\circ} \mathrm{C}$ until analyses at Otsuka Assay Institute, Tokushima, Japan. Adiponectin was determined using a validated sandwich ELISA employing an adiponectin-specific monoclonal and polyclonal antibody, which has been previously described $(6,7,11)$.

\section{Statistical analyses}

We assessed associations among variables with use of Pearson's correlation coefficient. Serum hs-CRP, TG, AI, insulin, HOMA ratio, leptin and adiponectin values were log-transformed to correct their skewed distributions. After dividing subjects into tertiles based on the distribution of control values for hs-CRP $(\sim<0.5 \mathrm{mg} / \mathrm{l}, 0.5 \leqq \sim<2.0,2.0 \leqq \sim)$ or mean \pm S.D. values $(8.4 \pm 2.8 \mu \mathrm{g} / \mathrm{ml})$ for adiponectin $(\sim<$ $6.0 \mu \mathrm{g} / \mathrm{ml}, 6.0 \leqq \sim<11.0,11.0 \leqq \sim)$, the differences across tertiles of various continuous parameters were tested with ANOVA. Stepwise linear regression models were fitted for log CRP, adiponectin/BFM or leptin/BFM as a dependent variable, including all variables of interest at the same time as independent variables to demonstrate the relative contribution of each of these variables to the outcome variable. The following independent variables were considered for the model: age, white blood cell count (WBC), blood urea nitrogen (BUN), diastolic blood pressure (BP), BMI, log-transformed AI, HOMA ratio, and/or CRP, and/or adiponectin/BFM, and/or leptin/BFM. All data are expressed as the mean \pm s.E.M. $P<0.05$ was considered statistically significant.

\section{Results}

WBC, BMI, BFM, TG, AI and leptin before and after adjustment for BMI or BFM were found to be correlated with serum hs-CRP levels (Table 1), while HDLC and adiponectin before and after adjustment for BMI or 
Table 1 Correlations between serum hs-CRP, adiponectin, adiponectin/BFM(\%) or leptin and various related parameters in 384 women.

\begin{tabular}{|c|c|c|c|c|}
\hline & hs-CRP $\#$ & Adiponectin ${ }^{\#}$ & Adiponectin/BFM ${ }^{\#}$ & Leptin ${ }^{\#}$ \\
\hline Age & $0.175^{\dagger}$ & $0.191^{\dagger}$ & 0.058 & 0.061 \\
\hline WBC & $0.229^{\ddagger}$ & $-0.227^{\ddagger}$ & $-0.212^{\dagger}$ & $0.152^{* *}$ \\
\hline Serum TP & $0.145^{\star \star}$ & $-0.128^{*}$ & $-0.188^{\dagger}$ & $0.162^{\star \star \star}$ \\
\hline Albumin & -0.066 & -0.108 & -0.093 & -0.040 \\
\hline BUN & $0.159^{\star *}$ & $0.231^{\dagger}$ & $0.174^{\star *}$ & -0.014 \\
\hline Creatinine & $0.140^{*}$ & $0.213^{\dagger}$ & $0.160^{*}$ & $0.124^{*}$ \\
\hline Uric acid & $0.183^{\dagger}$ & -0.051 & -0.099 & $0.190^{\dagger}$ \\
\hline Systolic BP & $0.183^{\dagger}$ & 0.022 & -0.054 & 0.098 \\
\hline Diastolic BP & 0.101 & -0.067 & $-0.160^{\star \star}$ & $0.245^{\ddagger}$ \\
\hline BMI & $0.254^{\ddagger}$ & $-0.253^{\ddagger}$ & $-0.556^{\ddagger}$ & $0.735^{\ddagger}$ \\
\hline BFM(\%) & $0.240^{\ddagger}$ & $-0.216^{\ddagger}$ & $-0.489^{\ddagger}$ & $0.744^{\ddagger}$ \\
\hline Serum TC & $0.145^{\star \star}$ & 0.065 & -0.090 & $0.218^{\ddagger}$ \\
\hline $\mathrm{TG}^{\#}$ & $0.251^{\ddagger}$ & $-0.306^{\ddagger}$ & $-0.398^{\ddagger}$ & $0.295^{\ddagger}$ \\
\hline HDLC & $-0.226^{\ddagger}$ & $0.352^{\ddagger}$ & $0.370^{\ddagger}$ & $-0.221^{\ddagger}$ \\
\hline $\mathrm{Al}^{\#}$ & $0.310^{\ddagger}$ & $-0.281^{\ddagger}$ & $-0.410^{\ddagger}$ & $0.365^{\ddagger}$ \\
\hline FBG & $0.150^{\star \star \star}$ & $-0.132^{\star}$ & $-0.178^{\star \star \star}$ & $0.110^{*}$ \\
\hline Fasting insulin" & 0.101 & $-0.377^{\ddagger}$ & $-0.470^{\ddagger}$ & $0.509^{\ddagger}$ \\
\hline HOMA ratio" & $0.120^{*}$ & $-0.364^{\ddagger}$ & $-0.459^{\ddagger}$ & $0.493^{\ddagger}$ \\
\hline Leptin" & $0.248^{\ddagger}$ & $-0.346^{\ddagger}$ & $-0.567^{\ddagger}$ & - \\
\hline Leptin/BMI ${ }^{\#}$ & $0.216^{\ddagger}$ & $-0.337^{\ddagger}$ & $-0.509^{\ddagger}$ & $0.978^{\ddagger}$ \\
\hline Leptin/BFM" ${ }^{\#}$ & $0.215^{\ddagger}$ & $-0.332^{\ddagger}$ & $-0.475^{\ddagger}$ & $0.955^{\ddagger}$ \\
\hline Adiponectin" & $-0.248^{\ddagger}$ & - & $0.925^{\ddagger}$ & $-0.346^{\ddagger}$ \\
\hline Adiponectin/BMI" & $-0.296^{\ddagger}$ & $0.957^{\ddagger}$ & $0.984^{\ddagger}$ & $-0.525^{\ddagger}$ \\
\hline Adiponectin/BFM ${ }^{\#}$ & $-0.313^{\ddagger}$ & $0.925^{\ddagger}$ & - & $-0.567^{\ddagger}$ \\
\hline
\end{tabular}

${ }^{\star} P<0.05,{ }^{* \star} P<0.01,{ }^{* \star *} P<0.005,{ }^{\dagger} P<0.001,{ }^{\ddagger} P<0.0001$. ${ }^{*}$ Log-transformed statistics.

BFM were inversely correlated (all $P<0.0001$ ). Apparent associations (correlation coefficients $>0.3$ ) were found between CRP and AI (positively), and adiponectin/BFM (inversely). Plasma adiponectin levels correlated inversely with WBC, BMI, BFM, TG, AI, insulin, HOMA ratio and leptin before and after adjustment (all $P<0.0001$ ), while positively with serum creatinine (Cr), BUN and HDLC (all $P<0.001$ ). These inverse associations became stronger after adjustment for BFM (all $P<0.0001$ ) (Table 1). Serum leptin levels correlated positively with diastolic BP, BMI, BFM, TC, TG, $\mathrm{AI}$, insulin and HOMA ratio (all $P<0.0001$ ), while inversely with HDLC and adiponectin before and after adjustment (all $P<0.0001$ ) (Table 1 ).

Table 2 shows the ANOVA data according to the tertile of hs-CRP or adiponectin levels in plasma. The women who had a low-grade CRP elevation (tertile 3) were significantly older, with increased WBC, and had significantly higher serum total protein (TP), BUN, Cr, UA, BMI, BFM, TC, TG, AI, FBG and leptin concentrations before and after adjustment, while lower HDLC and adiponectin concentrations before and after adjustment compared with the values of the tertile 1 . Women who had high plasma adiponectin levels (tertile 3) were significantly older, and had significantly lower WBC, CRP, BMI, BFM, TG, AI, FBG, insulin, HOMA ratio and leptin concentrations before and after adjustment, while higher BUN, Cr and HDLC levels compared with the values of the tertile 1 (Table 2).

As shown in Table 3, log-transformed hs-CRP was independently associated with WBC, BUN and AI and inversely with adiponectin/BFM in women in the stepwise regression analysis model. In contrast, age, diastolic BP, BMI, HOMA ratio and leptin/BFM were not related to the hs-CRP concentrations. Log-transformed leptin/BFM was independently associated with BMI and HOMA ratio and inversely with adiponectin/BFM (Table 3). In contrast, age, WBC, CRP, BUN, diastolic $\mathrm{BP}$ and AI were not independently related to the leptin/BFM values. Moreover, log-transformed adiponectin/BFM was independently associated with age and BUN, and inversely with WBC, CRP, BMI, AI, HOMA ratio and leptin/BFM in women in the stepwise regression analysis model (Table 3).

\section{Discussion}

In the present study, we have confirmed that CRP, a sensitive marker of inflammation that has previously been associated with CAD, was independently related to serum leptin and various parameters of metabolic syndrome X in nondiabetic women (16-18). Our principal finding was that plasma adiponectin before and after adjustment for BMI or BFM had a significantly negative association with CRP and WBC levels. Moreover, the association of low adiponectin with elevated CRP levels found in the present study could potentially explain the anti-inflammatory effect of adiponectin in vivo. CRP and WBC levels are considered to be influenced not only by chronic inflammation but also potentially by the presence of obesity and metabolic 
Table 2 Relationship between stratified serum hs-CRP or adiponectin and the various related parameters. Data are means \pm S.E.M. Significance of tertile 2 or 3 is the comparison with tertile 1.

\begin{tabular}{|c|c|c|c|c|c|c|}
\hline \multirow[b]{2}{*}{ Variables } & \multicolumn{3}{|c|}{ hs-CRP (mg/l) } & \multicolumn{3}{|c|}{ Plasma adiponectin $(\mu \mathrm{g} / \mathrm{ml})$} \\
\hline & $\begin{array}{l}\text { Tertile } 1 \\
(\sim<0.5)\end{array}$ & $(0.5 \leqq \stackrel{2}{\sim}<2.0)$ & $(2.0 \leqq \sim)$ & $\begin{array}{l}\text { Tertile } 1 \\
(\sim<6.0)\end{array}$ & $(6.0 \leqq \stackrel{2}{\sim}<11.0)^{2}<$ & $(11.0 \leqq \sim)$ \\
\hline$n(\%)$ & $221(57.6)$ & $112(29.2)$ & $51(13.3)$ & $103(26.8)$ & $206(53.6)$ & $75(19.5)$ \\
\hline Age (years) & $50.8 \pm 1.2$ & $57.4 \pm 1.4^{\dagger}$ & $57.5 \pm 2.1^{\star \star}$ & $50.9 \pm 1.8$ & $53.1 \pm 1.2^{\star \star \star}$ & $59.6 \pm 2.1^{* * *}$ \\
\hline WBC $\left(\times 10^{9} / \mathrm{I}\right)$ & $5.19 \pm 0.09$ & $5.63 \pm 0.16^{\star}$ & $6.10 \pm 0.25^{\dagger}$ & $5.80 \pm 0.16$ & $5.22 \pm 0.11^{\star}$ & $5.25 \pm 0.19 *$ \\
\hline hs-CRP ${ }^{\#}$ (mg/l) & $0.24 \pm 0.01$ & $1.07 \pm 0.04^{\ddagger}$ & $7.25 \pm 0.75^{\ddagger}$ & $2.2 \pm 0.4$ & $1.2 \pm 0.2^{\dagger}$ & $0.9 \pm 0.3^{\dagger}$ \\
\hline Serum TP $(g / l)$ & $74.2 \pm 0.3$ & $73.7 \pm 0.5$ & $77.5 \pm 0.8^{\ddagger}$ & $74.8 \pm 0.6$ & $74.4 \pm 0.4$ & $73.2 \pm 0.7$ \\
\hline Albumin $(\mathrm{g} / \mathrm{l})$ & $47.4 \pm 0.2$ & $46.6 \pm 0.3$ & $47.3 \pm 0.5$ & $47.3 \pm 0.4$ & $47.4 \pm 0.2$ & $46.0 \pm 0.4^{\star}$ \\
\hline $\mathrm{BUN}(\mathrm{mmol} / \mathrm{l})$ & $4.9 \pm 0.1$ & $5.3 \pm 0.2$ & $5.9 \pm 0.6^{\star \star}$ & $4.8 \pm 0.1$ & $5.0 \pm 0.1$ & $6.0 \pm 0.5^{\star \star}$ \\
\hline Creatinine ( $\mu \mathrm{mol} / \mathrm{l})$ & $52 \pm 1$ & $55 \pm 2$ & $65 \pm 9 * \star \star *$ & $50 \pm 1$ & $53 \pm 2$ & $67 \pm 5^{\ddagger}$ \\
\hline Uric acid $(\mu \mathrm{mol} / \mathrm{l})$ & $262 \pm 6$ & $286 \pm 6^{\star \star}$ & $303 \pm 12^{\dagger}$ & $286 \pm 6$ & $262 \pm 6^{\star}$ & $280 \pm 12$ \\
\hline Systolic BP (mmHg) & $141.2 \pm 1.3$ & $150.3 \pm 1.9^{\ddagger}$ & $146.4 \pm 2.6$ & $144.8 \pm 2.1$ & $144.4 \pm 1.5$ & $146.1 \pm 2.6$ \\
\hline Diastolic BP (mmHg) & $79.9 \pm 0.8$ & $81.9 \pm 0.9$ & $82.9 \pm 1.5$ & $81.1 \pm 1.0$ & $81.2 \pm 0.8$ & $78.4 \pm 1.3$ \\
\hline $\mathrm{BMI}\left(\mathrm{kg} / \mathrm{m}^{2}\right)$ & $21.9 \pm 0.2$ & $24.5 \pm 0.3^{\ddagger}$ & $23.7 \pm 0.6^{\dagger}$ & $24.0 \pm 0.4$ & $22.6 \pm 0.2^{\star \star \star}$ & $22.0 \pm 0.4^{\dagger}$ \\
\hline BFM (\%) & $28.6 \pm 0.4$ & $32.3 \pm 0.5^{\ddagger}$ & $31.7 \pm 0.9^{\dagger}$ & $31.8 \pm 0.6$ & $29.6 \pm 0.4^{\star \star \star}$ & $28.9 \pm 0.7^{* * *}$ \\
\hline Serum TC $(\mathrm{mmol} / \mathrm{l})$ & $5.18 \pm 0.07$ & $5.39 \pm 0.09$ & $5.54 \pm 0.14^{\star}$ & $5.26 \pm 0.10$ & $5.29 \pm 0.07$ & $5.41 \pm 0.12$ \\
\hline $\mathrm{TG}^{\#}(\mathrm{mmol} / \mathrm{l})$ & $0.95 \pm 0.03$ & $1.13 \pm 0.06^{\star}$ & $1.33 \pm 0.09^{\ddagger}$ & $1.32 \pm 0.07$ & $0.97 \pm 0.04^{\ddagger}$ & $0.85 \pm 0.04^{\ddagger}$ \\
\hline HDLC (mmol/l) & $1.75 \pm 0.03$ & $1.61 \pm 0.04^{\star \star \star}$ & $1.47 \pm 0.05^{\ddagger}$ & $1.47 \pm 0.04$ & $1.73 \pm 0.03^{\ddagger}$ & $1.83 \pm 0.05^{\ddagger}$ \\
\hline $\mathrm{Al}^{\#}$ & $2.1 \pm 0.1$ & $2.6 \pm 0.1^{\ddagger}$ & $3.0 \pm 0.2^{\ddagger}$ & $2.8 \pm 0.1$ & $2.2 \pm 0.1^{\ddagger}$ & $2.0 \pm 0.1^{\ddagger}$ \\
\hline $\mathrm{FBG}(\mathrm{mmol} / \mathrm{l})$ & $5.2 \pm 0.1$ & $5.5 \pm 0.1^{\star *}$ & $5.4 \pm 0.1^{*}$ & $5.5 \pm 0.1$ & $5.3 \pm 0.1^{*}$ & $5.2 \pm 0.1^{*}$ \\
\hline Fasting insulin" $(\mu \mathrm{U} / \mathrm{ml})$ & $6.6 \pm 0.3$ & $8.1 \pm 0.5^{\dagger}$ & $7.6 \pm 0.7$ & $9.5 \pm 0.6$ & $6.6 \pm 0.3^{\ddagger}$ & $5.7 \pm 0.5^{\ddagger}$ \\
\hline HOMA ratio $\#$ & $1.5 \pm 0.1$ & $2.0 \pm 0.1^{\dagger}$ & $1.9 \pm 0.2$ & $2.3 \pm 0.2$ & $1.6 \pm 0.1^{\ddagger}$ & $1.3 \pm 0.1^{\ddagger}$ \\
\hline Leptin" (ng/ml) & $6.8 \pm 0.3$ & $9.4 \pm 0.5^{\ddagger}$ & $9.7 \pm 0.9^{\dagger}$ & $9.3 \pm 0.5$ & $7.2 \pm 0.4^{\ddagger}$ & $6.6 \pm 0.7^{\ddagger}$ \\
\hline Leptin/BMI ${ }^{\#}$ & $0.29 \pm 0.01$ & $0.37 \pm 0.02^{\ddagger}$ & $0.38 \pm 0.03^{\dagger}$ & $0.38 \pm 0.02$ & $0.31 \pm 0.01^{\ddagger}$ & $0.28 \pm 0.03^{\ddagger}$ \\
\hline Leptin/BFM" & $0.22 \pm 0.01$ & $0.28 \pm 0.01^{\ddagger}$ & $0.29 \pm 0.02^{\star \star \star}$ & $0.29 \pm 0.01$ & $0.23 \pm 0.01^{\ddagger}$ & $0.22 \pm 0.02^{\ddagger}$ \\
\hline Adiponectin ${ }^{\#}(\mu \mathrm{g} / \mathrm{ml})$ & $9.1 \pm 0.3$ & $7.8 \pm 0.4^{\dagger}$ & $7.4 \pm 0.5^{\star \star \star}$ & $4.6 \pm 0.1$ & $8.4 \pm 0.1^{\ddagger}$ & $13.8 \pm 0.4^{\ddagger}$ \\
\hline Adiponectin/BMI & $0.43 \pm 0.01$ & $0.33 \pm 0.02^{\ddagger}$ & $0.33 \pm 0.03^{\dagger}$ & $0.20 \pm 0.01$ & $0.38 \pm 0.01^{\ddagger}$ & $0.65 \pm 0.03^{\ddagger}$ \\
\hline Adiponectin/BFM ${ }^{\#}$ & $0.33 \pm 0.01$ & $0.25 \pm 0.02^{\ddagger}$ & $0.26 \pm 0.04^{\ddagger}$ & $0.15 \pm 0.01$ & $0.29 \pm 0.01^{\ddagger}$ & $0.50 \pm 0.03^{\ddagger}$ \\
\hline
\end{tabular}

\# Log-transformed statistics.

${ }^{\star} P<0.05,{ }^{* \star} P<0.01,{ }^{* \star \star} P<0.005,{ }^{\dagger} P<0.001,{ }^{\ddagger} P<0.0001$.

syndrome X (15-18). Hypoadiponectinemia may contribute to serum CRP elevation in obesity and metabolic syndrome X. Future trials are needed to test the changes of plasma adiponectin in young patients with acute and chronic infection during and after treatment. The tendency for plasma adiponectin elevation in aged women may suggest the possibility that the prevalence of the accumulation of adiponectin to the injured endothelial barrier, accompanied with serum CRP elevation and the possible adiponectin production, increase with age. However, since adiponectin is presumed to form a homotrimeric subunit with a collagen-like triple-helical structure and circulates through the body as a multimer of trimers $(4,6)$, possible impaired adiponectin degradation in the aging may lead to an increase in plasma adiponectin concentration.

Table 3 Stepwise regression analyses of all variables of interest on hs-CRP or adiponectin/BFM or leptin/BFM. The $F$ value to enter was set at 4.0 at each step.

\begin{tabular}{|c|c|c|c|c|c|c|c|c|c|}
\hline \multirow[b]{2}{*}{ Independent variable } & \multicolumn{3}{|c|}{ hs-CRP" } & \multicolumn{3}{|c|}{ Adiponectin/BFM ${ }^{\#}$} & \multicolumn{3}{|c|}{ Leptin/BFM" } \\
\hline & $r^{2}$ & $\beta$ & $F$ & $r^{2}$ & $\beta$ & $F$ & $r^{2}$ & $\beta$ & $F$ \\
\hline - & 0.254 & - & - & 0.493 & - & - & 0.386 & - & - \\
\hline Age & - & - & 1.509 & - & 0.180 & 10.052 & - & - & 3.803 \\
\hline WBC & - & 0.228 & 14.973 & - & -0.111 & 4.872 & - & - & 0.235 \\
\hline hs-CRP ${ }^{\#}$ & - & - & - & - & -0.132 & 5.748 & - & - & 2.114 \\
\hline BUN & - & 0.197 & 11.059 & - & 0.146 & 7.726 & - & - & 1.738 \\
\hline Diastolic BP & - & - & 0.292 & - & - & 0.240 & - & - & 0.020 \\
\hline BMI & - & - & 1.155 & - & -0.327 & 27.163 & - & 0.374 & 31.428 \\
\hline $\mathrm{Al}^{\#}$ & - & 0.254 & 16.651 & - & -0.191 & 11.237 & - & - & 0.013 \\
\hline HOMA ratio ${ }^{\#}$ & - & - & 0.606 & - & -0.172 & 9.465 & - & 0.228 & 14.427 \\
\hline Leptin/BFM" ${ }^{\#}$ & - & - & 1.112 & - & -0.122 & 4.050 & - & - & - \\
\hline Adiponectin/BFM" & - & -0.204 & 10.018 & - & - & - & - & -0.155 & 5.494 \\
\hline
\end{tabular}

\# Log-transformed statistics. 
TNF- $\alpha$ has been suggested to play a role in the pathogenesis of metabolic syndrome X, and TNF- $\alpha$ mRNA is significantly elevated in adiposity and insulin resistance $(20,21)$. Crystal structure analysis revealed topological homology among the mouse adiponectin homolog, ACRP 30 and TNF- $\alpha$, which have an evolutionary link (22). Ouchi et al. (3) have shown that adiponectin has an inhibitory effect on the expression of TNF- $\alpha$ and adhesion molecules in vitro. We suggest that the hypoadiponectinemia associated with the components of metabolic syndrome $X(6,8-11)$ cannot reduce increased TNF- $\alpha$ action in the chronic inflammatory state, thus cannot suppress the elevation of serum CRP levels. Furthermore, we have to consider the possibility that the increased TNF- $\alpha$ in the inflammatory state may lead to decreased concentration of adiponectin. Indeed, a previous report showed that TNF- $\alpha$ inhibited adipose most-abundant gene transcript 1 secretion in an adipose cell line (23). This induced hypoadiponectinemia may accelerate the atherogenic reaction in subjects with an inflammatory state. Moreover, since recombinant adiponectin administration has been reported to inhibit lipopolysaccharide-induced TNF- $\alpha$ production and TNF- $\alpha$ mRNA expression in macrophages (5), it may have the possibility of therapeutic applications in diseases caused by systemic severe inflammatory responses such as septic shock and/or multiple organ failure.

Leptin correlates with markers of metabolic syndrome X, such as obesity, insulin resistance, hypertension and dyslipidemia (12-14). Soderberg et al. $(24,25)$ reported that plasma leptin was an independent risk factor for acute myocardial infarction and hemorrhagic stroke. Further, Wallance et al. (26) reported that leptin linked to CRP levels, and was a robust predictor of risk for CAD in men. Our results show the correlation between serum CRP and leptin, and the parameters of metabolic syndrome X may also provide further support for a link between adipocyte function and CAD. Kissebah et al. (27) have demonstrated two quantitative trait loci that influence the phenotypes of the insulin resistance-metabolic syndrome; one is located on chromosome 3q27 where the adiponectin gene is encoded (28), and the other is on $17 \mathrm{p} 12$ that is strongly linked to serum leptin.

Several experimental studies suggest a direct role of CRP in the initiation and progression of atherosclerotic lesions (15-17). CRP, a liver-derived protein, is regulated by interleukin-6 (IL-6), which is produced by inflammatory cells. Adding the production of IL-6 and TNF- $\alpha$ in adipocytes, our observations strongly suggest the possibility that adipose tissue may contribute to the inflammation. Because both adiponectin and leptin were reported to be involved in the pathophysiology of metabolic syndrome $\mathrm{X}$ and $\mathrm{CAD}$, the existence of a linkage between inflammation/adipose tissue/atherosclerosis can be suggested.

\section{Conclusions}

We found significant reduction of plasma adiponectin in women with low-grade CRP elevation, and these two proteins were inversely correlated before and after adjustment for body composition. Adding the associations with leptin, these factors may contribute to the well-known relationship between inflammation and atherosclerosis risk, suggesting the existence of the linkage of inflammation/adipose tissue/atherosclerosis.

\section{References}

1 Maeda K, Okubo K, Shimomura I, Funahashi T, Matsuzawa Y \& Matsubara K. cDNA cloning and expression of a novel adipose specific collagen-like factor, apMI (adipose most abundant gene transcript 1). Biochemical and Biophysical Research Communications $1996221286-289$.

2 Okamoto Y, Arita Y, Nishida M, Muraguchi M, Ouchi N, Takahashi $\mathrm{M}$ et al. An adipocyte-derived plasma protein, adiponectin, adheres to injured vascular walls. Hormone and Metabolic Research 200032 47-50.

3 Ouchi N, Kihara S, Arita Y, Maeda K, Kuriyama H, Okamoto Y et al. Novel modulator for endothelial adhesion molecules: adipocyte-derived plasma protein adiponectin. Circulation 1999 100 2473-2476.

4 Yokota T, Oritani K, Takahashi I, Ishikawa J, Matsuyama A, Ouchi $\mathrm{N}$ et al. Adiponectin, a new member of the family of soluble defense collagens, negatively regulates the growth of myelomonocytic progenitors and the functions of macrophages. Blood 2000 96 1723-1732.

5 Ouchi N, Kihara S, Arita Y, Nishida M, Matsuyama A, Okamoto Y et al. Adipocyte-derived plasma protein, adiponectin, suppresses lipid accumulation and class A scavenger receptor expression in human monocyte-derived macrophages. Circulation $2001 \mathbf{1 0 3}$ 1057-1063.

6 Arita Y, Kihara S, Ouchi N, Takahashi M, Maeda K, Miyagawa J et al. Paradoxical decrease of an adipose-specific protein, adiponectin, in obesity. Biochemical and Biophysical Research Communications $1999 \mathbf{2 5 7} 79-83$.

7 Matsubara M, Maruoka S \& Katayose S. Inverse relationship between plasma adiponectin and leptin concentrations in normal-weight and obese women. European Journal of Endocrinology 2002147 173-180.

8 Hotta K, Funahashi T, Arita Y, Takahashi M, Matsuda M, Okamoto Y et al. Plasma concentrations of a novel, adiposespecific protein, adiponectin, in type 2 diabetic patients. Arteriosclerosis, Thrombosis and Vascular Biology $2000201595-1599$.

9 Hotta K, Funahashi T, Bodkin NL, Ortmeyer HK, Arita Y, Hansen $\mathrm{BC}$ et al. Circulating concentrations of the adipocyte protein adiponectin are decreased in parallel with reduced insulin sensitivity during the progression to type 2 diabetes in rhesus monkeys. Diabetes 200150 1126-1133.

10 Stefan N, Vozarova B, Funahashi T, Matsuzawa Y, Weyer C, Lindsay RS et al. Plasma adiponectin concentration is associated with skeletal muscle insulin receptor tyrosine phosphorylation, and low plasma concentration precedes a decrease in wholebody insulin sensitivity in humans. Diabetes $2002 \mathbf{5 0}$ 1884-1888.

11 Matsubara M, Maruoka S \& Katayose S. Decreased plasma adiponectin concentrations in women with dyslipidemia. Journal of Clinical Endocrinology and Metabolism 200287 2764-2769.

12 Auwerx J \& Staels B. Leptin. Lancet $1998351737-742$.

13 Mantzoros CS. The role of leptin in human obesity and disease: a review of current evidence. Annals of Internal Medicine 1999130 $671-680$. 
14 Matsubara M, Chiba H, Maruoka S \& Katayose S. Elevated serum leptin concentrations in women with components of multiple risk factor clustering syndrome. Journal of Atherosclerosis and Thrombosis 20007 231-237.

15 Ridker PM, Hennekens CH, Buring JE \& Rifai N. C-reactive protein and other markers of inflammation in the prediction of cardiovascular disease in women. New England Journal of Medicine 2000 $342836-843$.

16 Ridker PM. High-sensitivity C-reactive protein. Potential adjunct for global risk assessment in the primary prevention of cardiovascular disease. Circulation 2001103 1813-1818.

17 Libby P, Ridker PM \& Maseri A. Inflammation and atherosclerosis. Circulation 2002105 1135-1143.

18 Festa A, D’Agostino R, Howard G, Mykkanen L, Tracy RP \& Haffner SM. Chronic subclinical inflammation as part of the insulin resistance syndrome. Circulation $200010242-47$.

19 Matthews DR, Hosker JP, Rudenski AS, Naylor BA, Treacher DF \& Turner RC. Homeostasis model assessment: insulin resistance and beta-cell function from fasting plasma glucose and insulin concentrations in man. Diabetologia 198528 412-419.

20 Hotamisligil GS, Arner P, Caro JF, Atkinson RL \& Spiegelman BM. Increased adipose tissue expression of tumor necrosis factor- $\alpha$ in human obesity and insulin resistance. Journal of Clinical Investigation $1995952409-2415$.

21 Hotamisligil GS, Peraldi P, Budavari A, Ellis R, White MF \& Spiegelman BM. IRS-1-mediated inhibition of insulin receptor tyrosine kinase activity in TNF-alpha- and obesity-induced insulin resistance. Science $1996 \mathbf{2 7 1} 665-668$.

22 Shapiro L \& Scherer PE. The crystal structure of a complement-1q family protein suggests an evolutionary link to tumor necrosis factor. Current Biology $1998 \mathbf{8} 335-338$.
23 Kappes A \& Loffler G. Influences of ionomycin, dibutyrylcycloAMP and tumor necrosis factor-alpha on intracellular amount and secretion of apM1 in differentiating primary human preadipocytes. Hormone and Metabolic Research 200032 $548-554$

24 Soderberg S, Ahren B, Stegmayr B, Johnson O, Wiklund PG, Weinehall L et al. Leptin is a risk marker for first-ever hemorrhagic stroke in a population-based cohort. Stroke 199930 328-337.

25 Soderberg S, Ahren B, Jansson JH, Johnson O, Hallmans G, Asplund $\mathrm{K}$ et al. Leptin is associated with increased risk of myocardial infarction. Journal of Internal Medicine $1999246409-418$.

26 Wallance AM, McMahon AD, Packard CJ, Kelly A, Shepherd J, Gaw A et al. Plasma leptin and the risk of cardiovascular disease in the West of Scotland Coronary Prevention Study (WOSCOPS). Circulation $20011043052-3056$.

27 Kissebah AH, Sonnenberg GE, Myklebust J, Goldstein M, Broman K, James RG et al. Ouantitative trait loci on chromosomes 3 and 17 influence phenotypes of the metabolic syndrome. PNAS 200097 14478-14483.

28 Takahashi M, Arita Y, Yamagata K, Matsukawa Y, Okutomi K, Horie $\mathrm{M}$ et al. Genomic structure and mutations in adiposespecific gene, adiponectin. International Journal of Obesity 2000 24 861-868.

Received 5 November 2002

Accepted 10 March 2003 